\title{
PRINSIP DASAR OPERASIONAL PERBANKAN SYARIAH, PRODUK-PRODUK DAN TANTANGANNYA
}

\author{
Ovenview
}

\begin{abstract}
Nasser Atorf *)
Krisis nilai tukar yang terjadi pada pertengahan 1997 telah membuat perbankan nasional mengalami kondisi yang sangat memprihatinkan. Hal tersebut ditandai dengan besarnya hutang dalam valuta asing yang melonjak, tingginya non performing loans, dan menurunnya permodalan bank. Kondisi tersebut diperburuk lagi dengan suku bungayang meningkat tajam sejalan dengan kebijakan moneter untuk meredam gejolak nilai tukar , sehingga banyak bank yang mengalami negatif spread. Kondisi perbankan yang sangat parah tersebut terutama sebagai akibat dari pengelolaan bank yang tidak berhati-hati. Dipihak lain terdapat pandangan dari para ahli bahwa penerapan sistem bunga telah memperparah terpuruknya sistem perbankan nasional.

Mengingat peranan perbankan sebagai motor penggerak ekonomi membuat dampak yang diakibatkan oleh ambruknya sistim perbankan nasional telah merusak sendi-sendi perekonomian nasional. Pemerintah telah berusaha melakukan penyehatan lembaga perbankan sebagai akibat krisis melalui program penjaminan, rekapitalisasi maupun restrukturisasi kredit. Sementara itu hal yang tidak kalah pentingnya adalah program pemantapan ketahanan sistem perbankan nasional sebagai antisipasi untuk menghadapi kemungkinan terulangnya krisis perbankan dimasa depan. Salah satu hal yang penting dalam mendukung ketahanan perbankan nasional adalah pada maju dan berkembangnya sistim perbankan syariah. Sehubungan dengan hal tersebut maka dalam penerbitan buletin kali ini kami sajikan kepada para pembaca yang budiman berbagai tulisan tentang perbankan syariah, sebagai suatu faktor pendukung dalam pengembangan perbankan nasional.

Sebagaimana diketahui bahwa bank syariah mulai diperkenalkan di Indonesia pada tahun 1992 sejalan dengan diberlakukannya Undang-undang No.7 Tahun 1992 tentang Perbankan. Namun perkembangan bank syariah tidak semaju bank konvensional. Dengan diberlakukannya Undang-undang N o.10Tahun 1998tentang perubahan Undang-undang
\end{abstract}

\footnotetext{
*) Nasser Atorf : Ketua Tim Penelitian Manajemen dan Operasional Bank Konvensional, Direktorat Penelitian dan Pengaturan Perbankan, Bank Indonesia.
} 
N o.7 Tahun 1992, diharapkan perbankan syariah dapat berkembang lebih baik dan dapat menjadi salah satu komponen penting dalam upaya pengembangan indutri perbankan indonesia. Hal tersebut mengingat dalam Undang-undang No.10tersebutperbankan syariah diberikan peluang yang lebih luas menjalankan kegiatan usahanya, termasuk pemberian kesempatan kepada perbankan konvensional untuk membuka kantor cabang yang khusus melakukan kegiatan usaha berdasarkan prinsip syariah. Dengan berkembangnya bank syariah diharapkan mobilisasi dana dan potensi ekonomi masyarakat muslim dapat dioptimalkan yang pada gilirannya akan semakin meningkatkan peran sektor perbankan secara keseluruhan.

Dasar pemikiran pengembangan bank syariah adal ah untuk memberikan pelayanan jasa kepada sebagian masyarakat Indonesiayang tidak dapat dilayani oleh perbankan yang sudah ada, karena bank-bank tersebut menggunakan sistem bunga. Dalam tulisan tentang prinsip dasar operasional perbankan syariah, Achmad Baraba antara lain menjelaskan bahwa dalam menjalankan operasinya, bank syariah tidak mengenal konsep bunga uang dan tidak mengenal peminjaman uang tetapi yang ada adalah kemitraan/ kerjasama (mudharabah dan musyarakah ) dengan prinsip bagi hasil, sementara peminjaman uang hanya dimungkinkan untuk tujuan sosial tanpa adanya imbalan apapun. Sehingga dalam operasinya dikenal beberapa produk bank syariah antara lain produk dengan prinsip mudharabah (perjanjian antara pihak pertama/ pemilik dana dan pihak kedua/ pengelola) dengan menyepakati nisbah bagi hasil atas keuntungan yang akan diperoleh sedangkan kerugian yang timbul menjadi resiko pemilik dana sepanjang tidak ada bukti bahwa pihak pengelola tidak melakukan kecurangan. Prinsip musyarakah adalah perjanjian antar pihak untuk menyertakan modal dalam suatu kegiatan ekonomi dengan pembagian keuntungan atau kerugian sesuai nisbah yang disepakati.

Sementaraitu pengembangan produk bank syariah tidaklah mudah, karena produkproduk bank syariah harus dikembangkan mengikuti karakter dan sifat produk syariah yang berbeda satu dengan yang lain, sebagaimana diutarakan oleh Cecep M. Hakim dalam tulisannya tentang problem pengembangan produk bank syariah. Sementara resiko dan jangka waktu merupakan faktor kedua sesudah dipahaminya karakter dan sifat produk syariah. A pabila konsep tersebut tidak dipegang dengan baik, maka para bankir akan condong untuk membuat produk yang lebih mendekati kepada produk-produk bank konvensional dengan alasan lebih mudah dihitung, mudah dibandingkan dan jelas ukurannya. Bagaimana sulitnya dalam pengembangan produk syariah dijelaskan pula bahwa sejak berdirinya Bank Muamalat Indonesia pada 1992 baru dua macam produk (Murabahah dan Bai ‘ Bitsaman Ajil) saja yang terus dipergunakan. Sehingga dalam hal ini perlu kajian secara terus menerus untuk mencari jenis atau produk syariah yang cocok untuk dikembangkan di dalam masyarakat. 
Dengan keberadaan perbankan syariah maka kedepan dimungkinkan pula terbentuknya lembaga-lembaga keuangan syariah. Untuk hal tersebut $\mathrm{H}$. Karnaen A. Perwataatmadja dalam tulisannya mengenai konsep, operasionalisasi, dan prospek pegadaian syariah di Indonesia menjelaskan bahwa lembaga gadai syariah antara pribadi dengan bank syariah, khususnya gadai fidusia sudah berjalan, dengan contoh pinjaman bank dengan agunan sertifikat tanah, saham, sertfikat deposito dan lain-lain. Sehingga lembaga gadai syariah pada perbankan syariah merupakan sesuatu yang biasa dalam praktek. Namun karena adanya ketentuan hukum positif yang berlaku, menyebabkan bankbank sekarang ini tidak diperkenankan menerima agunan dan menyimpan gadai barang bergerak. Selanjutnya karena gadai dalam hukum islam merupakan pelengkap dari hubungan hutang-piutang, sehingga operasionalisasi gadai pada bank syariah sudah berjalan walupun perlu penyempurnaan. Sementara pada perusahaan pegadaian yang sudah ada dimungkinkan untuk menjalankan gadai syariah apabila ada pemahaman dan kemauan yang kuat untuk menerapkan prinsip-prinsip syariah.

Sebagai lembaga kepercayaan, bank syariah dalam operasionalnya harus menjaga ketersediaan likuiditas seperti hal nya pada bank konvensional. Namun demikian, mengingat keterbatasan dari bank syariah untuk melakukan akses dana kepasar, maka perlu perlu dibuat sarana maupun piranti yang mendukung operasional dari bank syariah. Zainul A rifin dalam tulisannya tentang strategi pengembangan pasar uang syariah, menyatakan bahwa sumber dana bank syariah terdiri dari modal, kuasi ekuitas (mudharabah accounts) dan titipan (wadiah/ non remunerated deposits ). Ruang lingkup bank syariah bersifat universal banking, meliputi commercial banking dan investment banking. N amun sistem perbankan syariah secara prinsip berbeda dal am dengan sistem konvensional sehingga membawa konsekuensi perlunya pengaturan yang berbeda dengan bank konvensional misalnya tentang pola pengendalian likuiditas, perhitungan kecukupan modal dan sebagainya. Untuk menghindari posisi mismatch, bank Syariah harus memperoleh akses pendanaan dipasar uang. Untuk menciptakan pasar uang yang bermanfaat bagi bank syariah, perlu diciptakan instrumen pasar uang yang berbasis syariah dan diciptakan infrastruktur bagi mekanisme operasi pasar uang syarih. Berkaitan dengan pengembangan bank syariah tersebut, Bank Indonesia pada bulan Maret 2000 telah mengeluarkan ketentuan antara lain tentang Pasar Uang Antar Bank Syariah dan Sertifikat Wadiah Bank Indonesia.

Salah satu kendala yang dihadapi dalam pengembangan bank syariah di Indonesia adalah pemahaman anggota-anggota masyarakat mengenai kegiatan operasional bank syariah. Meskipun banyak masyarakat yang membutuhkan dan mendambakan keberadaan bank berdasarkan prinsip syariah, namun pada kenyataannya mereka belum memahami sepenuhnya produk, mekanisme, sistem, dan seluk beluk bank syariah. Memang dibandingkan dengan negara tetangga seperti Malaysiayang telah cukup lama menerapkan 
sistim perbankan syariah, maka praktek perbankan syariah di Indonesia boleh dikata masih memasuki tahap awal. Disamping itu pengembangan bank syariah juga memerlukan pola konsumsi dari masyarakat secara islam dan dijalankan secara konsisten (istiqamah). Hal tersebut seperti yang diungkapkan dalam tulisan Mulya E. Siregar, bahwa bila konsumsi masyarakat telah islami, maka rumah tangga akan selalu mempertimbangkan kepentingan akhirat dalam setiap keputusan ekonomi yang akan diambil, termasuk dalam memilih jasa perbankan. Salah satu konsumsi untuk akhirat adalah dengan ber-zakat. Selanjutnya dengan terciptanya perilaku konsumen yang sedemikian rupa dan berjalan secara konsisten akan memudahkan pengembangan bank syariah.

Jumlah penduduk yang mayoritas beragama Islam dan banyaknya anggota masyarakat yang enggan berhubungan dengan bank konvensional, merupakan potensi yang besar bagi pengembangan bank dengan prinsip syariah. Namun sebagaimana diuraikan di atas perlu adanya kesiapan masyarakat dalam memahami apa itu bank syariah. Hal tersebut sejalan dengan tulisan dari Zainul bahar Noor tentang Islam dan tantangan ekonomi yang disarikan dari buku Umar Chapra, bahwa umat islam tidak usah berpaling kedunia Barat atau ke dunia Timur dalam mewujudkan kesejahteraan, khususnya dalam bidang ekonomi, tetapi cukup berpaling pada Islam. Selama negara-negara yang mayoritas penduduknya beragama Islam terus menggunakan strategi kapitalis atau sosialis mereka tidak akan mampu berbuat melebihi negara kapitalis dan sosialis. Selanjutnya, Dhani Gunawan dalam tulisannya menjelaskan tentang perlunya paradigma baru dari masyarakat untuk lebih memahami opersional perbankan syariah. Untuk kedepan perbankan syariah harus dibangun dalam suatu sistem yang bebas dari praktek korupsi dan kolusi, disamping harus dihindarkan dari muatan politis. Terdapat beberapa tantangan yang dihadapi dalam pengembangan bank syariah yaitu sumber daya manusia yang profesional, kemampuan bank dalam menyediakan produk dan pengembangan teknologi.

Dalam bulein kali ini dimuat pula tulisan dari Mulya Siregar tentang manajemen moneter alternatif, yang antara lain mengungkapkan bahwa manajemen moneter yang mendasarkan pada suku bunga berpengaruh terhadap pemenuhan kebutuhan pokok dan pemerataan distribusi pendapatan. Hal tersebut disebabkan karena penyaluran pinjaman dengan suku bunga tertentu ditetapkan berdasarkan kemampuan peminjam memberikan jaminan kredit guna mengcover pinjaman yang diberikan dan kecukupan cash flow untuk memenuhi kewaji ban tersebut. Usaha-usaha mengatur money demand atau manajemen moneter melalui suku bunga cenderung memperkedi money demand untuk kegiatan pokok dan investasi yang produktif dan cenderung memperbesar money demand untuk kegiatan non produktif dan spekulatif, yang padagilirannya mengakibatkan kegagal an pencapaian tujuan pembangunan ekonomi suatu negara, karena money demand untuk konsumsi dan spekulasi cenderung lebih tidak stabil dan dapatmenimbulkan ketidakstabilan bagi perekonomian secarakeseluruhan. 